\title{
Assessment of Carbon Footprint of Upland Rice Production in Northern Thailand
}

\author{
Palika Champrasert $^{1}$, Sate Sampattagul ${ }^{2}$, Sanwasan Yodkhum ${ }^{2}$, \\ and Prasit Wangpakapattanawong ${ }^{1,3^{*}}$
}

\author{
${ }^{1}$ Environmental Science Research Center, Faculty of Science, Chiang Mai \\ University, Chiang Mai 50200, Thailand \\ ${ }^{2}$ Department of Mechanical Engineering, Faculty of Engineering, Chiang Mai \\ University, Chiang Mai 50200, Thailand \\ ${ }^{3}$ Department of Biology, Faculty of Science, Chiang Mai University, Chiang Mai \\ 50200, Thailand \\ *Corresponding author. E-mail: prasitwang@yahoo.com \\ https://doi.org/10.12982/CMUJNS.2020.0028
}

Received: June 10, 2019

Revised: August 8, 2019 Accepted: September 2, 2019

\begin{abstract}
Traditional slash-and-burn agriculture is practiced by the Lawa and the Karen in the highlands of Northern Thailand. The pattern involves planting upland rice for only one year and then leaving the land fallow for 6 years. This research aimed to assess the carbon footprints of upland rice production of this system by assessing the carbon footprint of land preparation and the life cycle greenhouse gas (GHG) emissions of upland brown rice production from seed planting to rice harvesting. It was found that carbon stock in the 6-year fallow forest was about 217.19-295.61 ton $\mathrm{CO}_{2}$-eq/ha. The GHG emission in the land preparation of the Karen was 37.65 ton $\mathrm{CO}_{2}-e q / h a$ while for the Lawa, it was shown the GHG absorption was 16.79 ton $\mathrm{CO}_{2}$-eq/ha. GHG emissions in the upland brown rice cultivation in the two tribes were 0.26 ton $\mathrm{CO}_{2}$-eq/ha $\left(0.13 \mathrm{~kg} \mathrm{CO} \mathrm{CO}_{2}\right.$ eq/kg unmilled rice $)$ in the Karen and 0.37 ton $\mathrm{CO}_{2-}$ eq/ha $\left(0.19 \mathrm{~kg} \mathrm{CO} \mathrm{C}_{2}-\mathrm{eq} / \mathrm{kg}\right.$ unmilled rice) in the Lawa. The tree cutting and slashing and biomass burning in the land preparation and chemical fertilizer production in cultivation produced the highest GHG emission from the upland rice production in the tradition slash-and-burn agriculture. However, this system was a carbon sink than a carbon source of about 233.61-257.70 ton $\mathrm{CO}_{2}$ eq/ha.
\end{abstract}

Keywords: GHGs, Karen, Lawa 


\section{INTRODUCTION}

Greenhouse gases (GHGs) emission is one of the most important issues in Thailand and around the world, and agriculture is one source of GHGs emission that is related to all human activities (IPCC, 2007).

Rice cultivation is one activity that has received attention as a source of long-lived greenhouse gases such as carbon dioxide $\left(\mathrm{CO}_{2}\right)$, methane $\left(\mathrm{CH}_{4}\right)$, and nitrous oxide $\left(\mathrm{N}_{2} \mathrm{O}\right)$. Cultivation can be done in 2 main ways, flooded fields (anaerobic rice or paddy rice) and non-flooded fields (aerobic rice or upland rice). Paddy rice is grown in flooded conditions where water can be supplied through irrigation systems. These conditions produce $\mathrm{CH}_{4}$ during the growing season due to methanogenesis that occurs in anaerobic conditions, during which organic matter undergoes decomposition. Upland rice production is under rainfed nonflooded conditions (Jain et al., 2004; Zheng et al., 2004; Li et al., 2005; IPCC, 2007; Arunrat and Pumijumnong, 2017). This study focused on upland rice production.

Some parts of Northern Thailand consist of high mountains that are incised by steep river valleys and upland areas. Part of Chiang Mai province is remote highlands where people have maintained a traditional way of life and have limited irrigation systems.

The Lawa and Karen in Northern Thailand practice upland rice swidden agriculture or rotation shifting cultivation by clearing areas, slashing vegetation, leaving large trees and tree stumps for regeneration, and burning. An upland rice field is cultivated for only one year, followed by fallowing the field for several years. Upland rice swidden agriculture is a communal activity.

The fallow forest can serve as a carbon storage in secondary forests and soils depending on the length of the fallow period and type of forests. The secondary forest after upland rice cultivation was a significant aboveground carbon sink (Rozendaal and Chazdon, 2015; Mukul et al., 2016). Land-use change in land preparation process, including forest clearing by cutting and slashing and burning, emitted greenhouse gases into the atmosphere (Scheidel, 2016; Boateng et al., 2017). Before burning, villagers remove some logs, boles, and branches of the slashed trees to be used for wooden sheds, house construction, and fences for their livestock. Cultivation of the area begins after holes are drilled by the men using hoes (zero tillage), then the women sow rice seeds in each of the holes. Weeds emerge after first monsoon rains and must be eradicated in the cropping season. The rice ripens to be harvested from October to November (Schmidt-Vogt, 1999; Cairns, 2007). The harvested rice is threshed by hand over the canvas on the ground to avoid de-husking the grains (unmilled rice) (Oikeh et al., 2008) and the rice straw is left in the field.

Upland rice is not cultivated under flooded conditions, $\mathrm{CH}_{4}$ can be produced in the upland field, but it is very low or minimal (Anand et al., 2005; IPCC, 2006; Khalil et al., 2011). Weller et al. (2014) reported that $\mathrm{CH}_{4}$ emission 
from upland rice was lower than from paddy rice. However, non-flooded rice can produce nitrous oxide $\left(\mathrm{N}_{2} \mathrm{O}\right)$ from chemical fertilizers and pesticide, applied to increase the rice yield in the rice field, that is released into the atmosphere during aerobic decomposition (nitrification and de-nitrification) by bacteria (Aweto, 2013; Weller et al., 2014) which is one cause of global warming (Holden, 1993; Tinker et al., 1996; IPCC, 2007; Higashi, 2014). $\mathrm{N}_{2} \mathrm{O}$ may increase in relation to the production, however, the $\mathrm{N}_{2} \mathrm{O}$ emission in this system is reduced by the hoeweeding by hand and zero tillage (Kreuz and Schäfer, 2011). Reducing GHG emissions of cultivation by farm management such as burning reduction, limiting chemical fertilizer and synthetic pesticide usages. It can help mitigating climate change, reducing environmental impact, reducing cultivation cost and human health care (AIPP and IWGIA, 2014; Wenzlau, 2019).

The greenhouse gas emission from rotation shifting cultivation is one of the most important issues in Northern Thailand while there is the paucity of literature on this problem. The purpose of this research was to determine carbon footprints of the upland rice production (unmilled rice) of the Lawa and the Karen tribes in Chiang Mai province, Thailand. The assessment of the environmental impact was also done to improve sustainability of rotation shifting cultivation system.

\section{MATERIALS AND METHODS}

\section{Study site}

The study site was located in secondary fallow forests of 6 years in the Karen and Lawa villages that are mountainous with steep slopes (more than 35\%) in Pang Hin Fon sub-district, Mae Cheam district, Chiang Mai province, Thailand. The location of the Lawa village was $18^{\circ} 27^{\prime} 21.60 " \mathrm{~N}, 98^{\circ} 10^{\prime} 51.60 " \mathrm{E}$ and the Karen village's was $18^{\circ} 25^{\prime} 40.80^{\prime \prime} \mathrm{N}, 9^{\circ} 8^{\prime} 16.80^{\prime \prime} \mathrm{E}$ (Figure 1). The annual average temperature in this district is $22.4^{\circ} \mathrm{C}$ with a mean maximum temperature of $31.7^{\circ} \mathrm{c}$ in Aprils and a mean minimum temperature of $13.8^{\circ} \mathrm{c}$ in Decembers. Mean humidity is 71.3\% (Mae Cheam Watershed Research Station, 2015). 


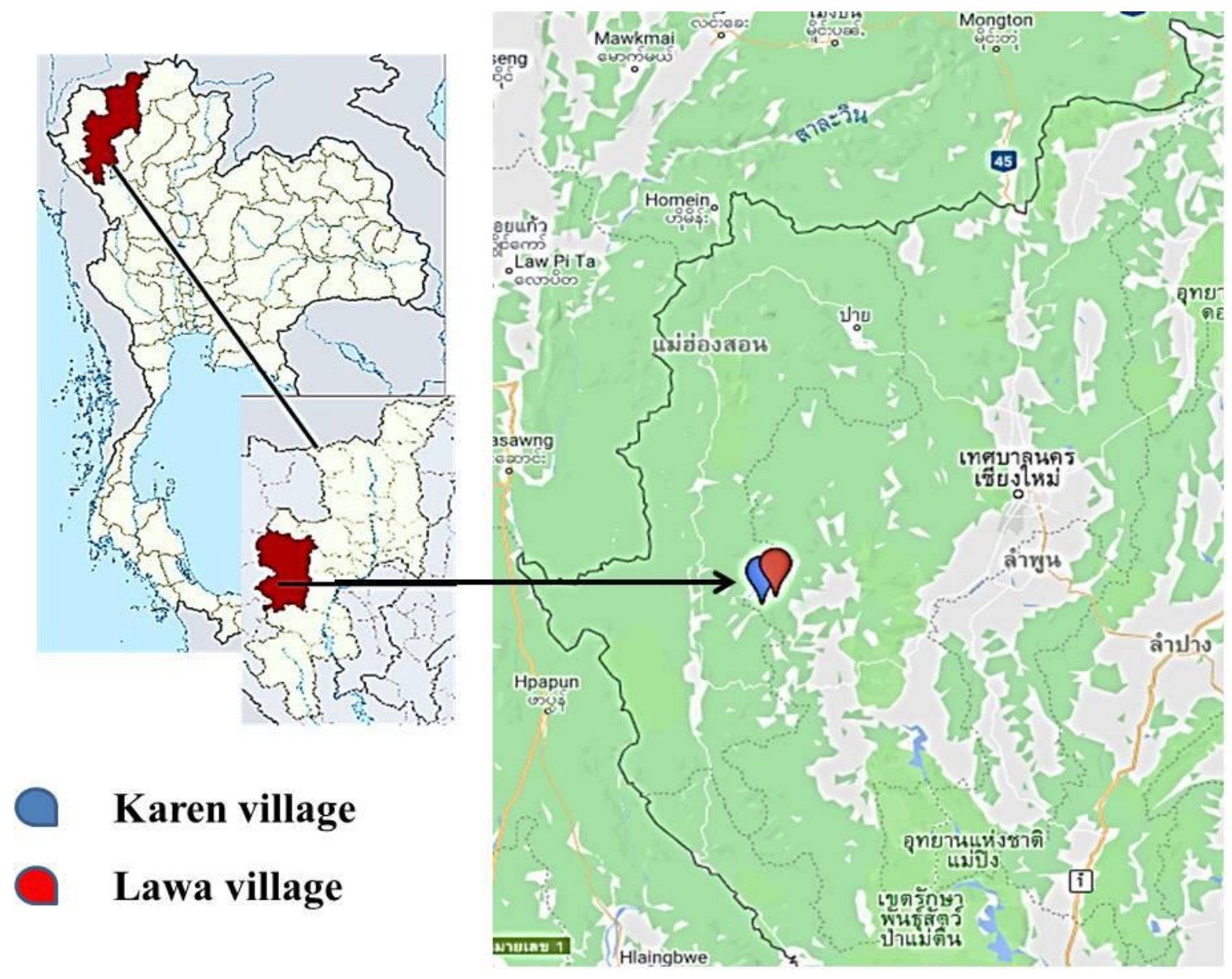

Figure 1. Rotation shifting cultivation area located in Mae Chaem district, Chiang Mai province, Thailand.

\section{Carbon footprint assessment}

The carbon and impact assessments of rotation shifting cultivation system for upland rice production of the two tribes including land-use change and upland rice cultivation were analyzed using life cycle assessment (LCA) method.

\section{Life cycle assessment (LCA)}

The LCA method has been wildly used in carbon footprint research. The standard LCA includes four phases consist of the goal and scope definition, inventory analysis, impact assessment, and interpretation, respectively (ISO14040, 2006; Nemecek et al., 2011).

Goal and scope definition. The goal of this research was to estimate the environmental impact of carbon within different processes, all impact values were given in relation to a common unit of unmilled rice grains $\left(\mathrm{CO}_{2}\right.$-equivalent greenhouse gas emission per kilogram of unmilled rice production) of the Lawa and the Karen tribes according to ISO 14040 (IPCC, 2006), excluding the milling and packaging. The system boundary of the upland rice production in this research included the stages of the upland rice production from land preparation to rice harvesting in 2015 (Figure 2). The cradle-to-farm gate or business-to- 
business (B2B) concept was used as the system boundaries for the carbon footprint product (Carbon trust, 2007; TGO, 2012; Sachakamol, 2016). The field burning emission was not used for this calculation because the rice straw was not burnt but left for rapid decay in the fields, which helped to improve soil fertility (Jeeva et al., 2006; Cairns, 2015).

The scope of the LCA included the functional unit (FU), which was defined as the quantity of the rice product, which in this case was 1 kilogram of unmilled rice $\left(\mathrm{kgCO}_{2}\right.$-eq $\cdot \mathrm{kg}^{-1}$ of unmilled rice).

Inventory analysis. The inventory analysis, including resources consumption and carbon emission $\left(\mathrm{CO}_{2}\right)$ in life cycle of upland rice from land preparation to harvesting, were collected while rice straw was estimated based on Kaizzi et al. (2014). The one-way transportation with 50\% loaded of all materials to the upland rice fields was used. Upland rice seeds were transported from their villages, a distance of 1.5 kilometers was used, including fertilizers, chemicals, and gasoline, for chemical application and transportation from retail stores and petrol station with the distance of 35.30 kilometers for the Lawa and 45.95 kilometers for the Karen, respectively. The inputs and outputs data were used to estimate mass balance per FU for calculating the carbon footprint.

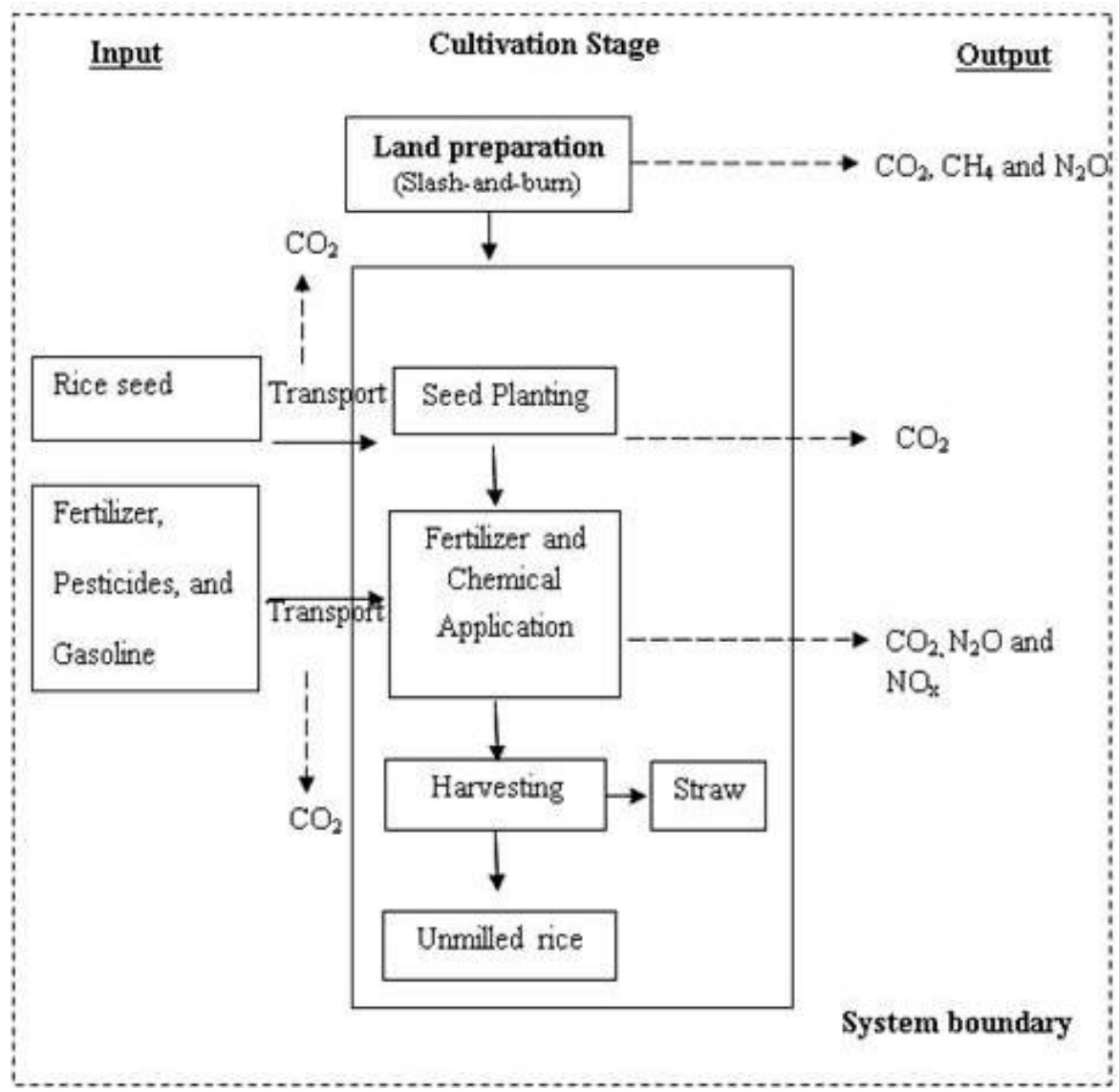

Figure 2. A system boundary of unmilled rice. 
Impact assessment. The impact assessment was done to assess the environmental impacts of production. The results were presented as $\mathrm{kgCO}_{2}$ equivalence $\left(\mathrm{kgCO}_{2}\right.$-eq) (Manitoba Eco-Network, 2016). The carbon emission was estimated by GHG emission, which was calculated as activity data and emission factors (Table 1) converted to emission values using global warming potential (GWP) (Table 2) for calculation as follows (Yuttitham, 2019).

$$
\mathrm{CO}_{2} \text { Emissions }\left(\mathrm{CO}_{2} \text {-eq }\right)=\quad(\text { Activity Data }) \times(\text { Emission Factor }) \times(\mathrm{GWP})
$$

Table 1.Emission factors used in the upland rice cultivation of the Karen and the Lawa.

\begin{tabular}{|c|c|c|c|}
\hline Activity data & Unit & $\begin{array}{l}\text { Emission factor } \\
\text { (kgCO2-eq/unit) }\end{array}$ & Reference \\
\hline \multicolumn{4}{|l|}{ Raw materials } \\
\hline -Rice seed & $\mathrm{kg}$ & 0.2500 & $\begin{array}{l}\text { Product Category Rules } \\
\text { (PCRs) of rice } \\
\text { (Rice department, 2010) }\end{array}$ \\
\hline $\begin{array}{l}\text {-Organic fertilizer } \\
\text {-Chemical fertilizer }\end{array}$ & $\mathrm{kg}$ & 0.1097 & TGO, 2015 \\
\hline Nitrogen $(\mathrm{N})$ & $\mathrm{kg}$ & 2.6000 & TGO, 2015 \\
\hline Phosphorus (P) & $\mathrm{kg}$ & 0.2520 & TGO, 2015 \\
\hline Potassium $(\mathrm{K})$ & $\mathrm{kg}$ & 0.1600 & TGO, 2015 \\
\hline -Soil amendment and other & $\mathrm{kg}$ & 0.0265 & TGO, 2015 \\
\hline -Herbicide & $\mathrm{kg}$ & 10.2089 & TGO, 2015 \\
\hline -Insecticide & $\mathrm{kg}$ & 16.5873 & $\begin{array}{l}\text { TGO, } 2015 \\
\text { Thai National LCI }\end{array}$ \\
\hline -Gasohol (crude oil) & $\mathrm{kg}$ & 0.7069 & $\begin{array}{l}\text { Database/MTEC, } 2015 \\
\text { (update June,2016) }\end{array}$ \\
\hline -Gasohol (combustion) & $\mathrm{L}$ & 2.1896 & $\begin{array}{l}\text { IPCC, } 2006 \\
\text { (update March,2013) }\end{array}$ \\
\hline Transportation & Tkm & 0.3145 & $\begin{array}{l}\text { Thai National LCI } \\
\text { Database/MTEC, } 2015 \\
\text { (update June,2016) }\end{array}$ \\
\hline
\end{tabular}

Note: $\mathrm{kg}$ is kilogram, $\mathrm{L}$ is liter, and Tkm is ton-kilometer.

Table 2. Global warming potential (GWP) values in relation to $\mathrm{CO}_{2}$.

\begin{tabular}{lc}
\hline Greenhouse gas & GWP values for 100-year time \\
\hline Carbon dioxide $\left(\mathrm{CO}_{2}\right)$ & 1 \\
Methane $\left(\mathrm{CH}_{4}\right)$ & 25 \\
Nitrous oxide $\left(\mathrm{N}_{2} \mathrm{O}\right)$ & 298 \\
\hline
\end{tabular}


The carbon released of the upland rice cultivation from land-use change in slash and burn process included carbon stock in the 6-year fallow forest and carbon emission from biomass burning, and upland rice cultivation including rice seeds, soil amendment (dolomite), organic fertilizer, chemical fertilizer, chemical pesticide, fuel (gasoline) for chemical application and lawnmowers, and transportation of the upland rice farming has been estimated, the emission of $\mathrm{CH}_{4}$ (burning), $\mathrm{CO}_{2}$ (dolomite), nitrous oxide $\left(\mathrm{N}_{2} \mathrm{O}\right)$ that combined with indirect nitrogen emission $\left(\mathrm{NO}_{\mathrm{x}}\right)$, and transportation were calculated as follows (IPCC, 2006; TGO, 2016)

The GHG emissions of the aboveground parts and the soils in land-use change were estimated using the carbon stock in the secondary fallow forests and carbon remaining in the upland rice fields after the slash and burn process. The carbon emission from the burning process was estimated from non- $\mathrm{CO}_{2}$ gas $\left(\mathrm{CH}_{4}\right.$ and $\mathrm{N}_{2} \mathrm{O}$ ) emission.

\section{- Aboveground parts}

The circumferences and heights of all the trees in the sampling plots of the secondary fallow forest were measured to calculate their volume and biomass using the allometric equations (Tsutsumi et al., 1983) as follows:

$$
\begin{aligned}
& \mathrm{W}_{\mathrm{s}}=0.0509\left(\mathrm{D}^{2} \mathrm{H}\right)^{0.919} \\
& \mathrm{~W}_{\mathrm{l}}=0.0140\left(\mathrm{D}^{2} \mathrm{H}\right)^{0.669} \\
& \mathrm{~W}_{\mathrm{b}}=0.00893\left(\mathrm{D}^{2} \mathrm{H}\right)^{0.977} \\
& \mathrm{~W}_{\mathrm{r}}=0.0313\left(\mathrm{D}^{2} \mathrm{H}\right)^{0.805}
\end{aligned}
$$

Where $\mathrm{W}_{\mathrm{s}}$ is stem biomass $(\mathrm{kg}), \mathrm{W}_{\mathrm{l}}$ is leaf biomass $(\mathrm{kg}), \mathrm{W}_{\mathrm{b}}$ is branch biomass $(\mathrm{kg}), \mathrm{W}_{\mathrm{r}}$ is root biomass $(\mathrm{kg}), \mathrm{H}$ is height $(\mathrm{m})$ and $\mathrm{D}$ is diameter at breast height (cm)

Moreover, ground flora was destructively determined for dried biomass and woody necromass in area was determined using line-intersect method to calculate dry mass. The carbon content was $50 \%$ of the biomass (Dixon et al., 1994).

Aboveground carbon $(\mathrm{kg} \mathrm{C} / \mathrm{ha})=\mathrm{DM} \times 0.5$

\section{- Soils}

The soil samples in each site were collected in 3 levels (0-10, 10-20 and 20-30 cm depth) (Watthanasuksakun et al., 2013) and soil organic matter was determined using the Walkley-Black method (Walkley and Black, 1934), and soil bulk density was determined by the core method (Blake and Hartge, 1986) in the field. The soil organic carbon was calculated as follows:

Soil organic carbon $(\mathrm{kg} \mathrm{C} / \mathrm{ha})=\mathrm{OC} \times \mathrm{BD} \times \mathrm{SD}$ 
Where OC is organic carbon values $(\mathrm{g} / 100 \mathrm{~g})$, BD is bulk density $\left(\mathrm{g} \mathrm{cm}^{-3}\right)$, and $\mathrm{SD}$ is soil depth $(\mathrm{cm})$

$$
\begin{gathered}
\text { GHG emission from LUC }=\left[\left(\mathrm{CS}_{\text {before }}-\mathrm{CS}_{\text {after }}\right) \times 44 / 12\right]+\mathrm{L}_{\text {fire }} \\
\mathrm{CS}=\text { Aboveground carbon }+ \text { Soil organic carbon } \\
\mathrm{L}_{\text {fire }}=\left[\mathrm{M}_{\mathrm{B}} \times \mathrm{C}_{\mathrm{f}} \times \mathrm{G}_{\mathrm{ef}, \mathrm{CH} 4} \times \mathrm{GWP}_{\mathrm{CH} 4}(25)\right]+\left[\mathrm{M}_{\mathrm{B}} \times \mathrm{C}_{\mathrm{f}} \times \mathrm{G}_{\mathrm{ef}, \mathrm{N} 2 \mathrm{O}} \times \mathrm{GWP}_{\mathrm{N} 2 \mathrm{O}}(298)\right]
\end{gathered}
$$

Where $\mathrm{CS}_{\text {before }}$ is the sum of carbon stock from aboveground carbon and soil carbon per unit area before the conversion $\left(\mathrm{kg} \mathrm{CO}_{2} \mathrm{eq} / \mathrm{ha}\right), \mathrm{CS}_{\text {after }}$ is the sum of carbon stock from aboveground carbon and soil carbon per unit area immediately after the conversion $\left(\mathrm{kg} \mathrm{CO} \mathrm{CO}_{2} \mathrm{ha}\right.$ ), $\mathrm{L}_{\text {fire }}$ is $\mathrm{GHG}$ (non- $\mathrm{CO}_{2}$ ) emissions from the biomass burnt ( $\left.\mathrm{kg} \mathrm{CO}_{2} \mathrm{eq} / \mathrm{ha}\right), \mathrm{MB}=$ mass of fuel for combustion (t/ha) including biomass, ground litter, and deadwood while Tier 1 methods are used then litter and deadwood pools are assumed zero, except where there is a land-use change, $\mathrm{C}_{\mathrm{f}}=$ combustion factor for fire in intermediate secondary tropical forest (6-10 years) (0.67), $\mathrm{G}_{\text {ef }}=$ emission factor for tropical forest $\left(\mathrm{CH}_{4}=6.8\right.$ and $\left.\mathrm{N}_{2} \mathrm{O}=0.20\right)$ ( $\mathrm{g} / \mathrm{kg}$ dry matter burnt).

$\mathrm{CO}_{2}$ emissions $($ Dolomite $)=$ Dolomite content $\times$ emission factor $(0.13) \times 44 / 12$

$\mathrm{N}_{2} \mathrm{O}$ emissions $=[\mathrm{N}$ content $\times$ emission factor $(0.003)] \times 44 / 28 \times \mathrm{GWP}_{\mathrm{N} 2 \mathrm{O}}(298)$

$\mathrm{NO}_{\mathrm{x}}$ emissions $=\left[\mathrm{N}\right.$ content $\times$ fraction $\left._{\mathrm{NH} 3-\mathrm{NOx}}(0.1)\right] \times$ emission factor $(0.01) \times$ $44 / 28 \times \operatorname{GWP}_{\mathrm{N} 2 \mathrm{O}}(298)$

$\mathrm{Etd}=\Sigma\left[\left(\mathrm{EF}_{\mathrm{T} 1, \mathrm{i}} \times \mathrm{W}_{\mathrm{T} 1, \mathrm{i}} \times \mathrm{T}_{\mathrm{T} 1, \mathrm{i}}\right)+\left(\mathrm{EF}_{\mathrm{T} 2, \mathrm{i}} / \mathrm{L}_{\mathrm{T} 2, \mathrm{i}} \times \mathrm{D}_{\mathrm{T} 2, \mathrm{i}}\right)\right.$

Where Etd is GHG emission caused by transportation of raw materials used $\left(\mathrm{kgCO}_{2}\right.$-eq/ha-year), $\mathrm{EF}_{\mathrm{T} 1, \mathrm{i}}$ is emission factors of vehicles used to transport material $\mathrm{i}\left(\mathrm{kg} \mathrm{CO} \mathrm{CO}_{2}\right.$-eq/Tkm), $\mathrm{W}_{\mathrm{T} 1, \mathrm{i}}$ is weight of the transported material $\mathrm{i}$ outbound trip (ton), $\mathrm{T}_{\mathrm{T} 1, \mathrm{i}}$ is transport distance for material $\mathrm{i}$ - outbound trip (km), $\mathrm{EF}_{\mathrm{T} 2, \mathrm{i}}$ is emission factor of vehicles used for transport material $\mathrm{i}$, at empty loaded assumption $\left(\mathrm{kg} \mathrm{CO}_{2}\right.$-eq/ $\left./ \mathrm{km}\right), \mathrm{L}_{\mathrm{T} 2, \mathrm{i}}$ is loading capacity of vehicles used (in this study $=0)($ ton $), \mathrm{D}_{\mathrm{T} 2, \mathrm{i}}$ is transportation distance of raw material $\mathrm{i}$ - return trip $(\mathrm{km})$

The total carbon footprint in each process was calculated per FU (1 kg of unmilled rice).

GHGs emission $=$ net GWP $/$ FU $(1 \mathrm{~kg}$ of unmilled rice $)$ 
Interpretation. This final step, the results of GHGs emission of each process were used to identify significant issues that were assessed, and to check for consistency, sensitivity, and completeness. Conclusions, recommendations, and reporting were based on the results of the inventory and impact assessment phases of the LCA of the upland rice cultivation (ISO, 2004; Curran, 2006; ISO, 2006; AquAeTer, 2016).

\section{Data collection and analysis}

Key informants were randomly selected for individual interviews. The data were collected using questionnaires about the upland rice cultivation in 2015 from 174 upland rice farmers in the two villages including 89 farmers, or about $96 \%$ of the Lawa village, and 85 farmers, or $68 \%$ of the Karen village. The sample sizes were calculated using the Yamane method (Yamane, 1967) as follows:

$$
\mathrm{n} \quad \frac{N}{1+N(e)^{2}}
$$

Where $\mathrm{n}$ is sample size, $\mathrm{N}$ is population size, $e$ is precision (the deviation of the sample (settle at 0.05: error of specifying the sample).

Secondary data were searched from research documents, reports, and journal articles.

\section{RESULTS}

The data were from the field surveys and the farmers' interviews. The GHG emission of the upland rice production in the rotation shifting cultivation of the Lawa and the Karen were estimated by the carbon stock change in land-use change from secondary fallow forest to upland rice field and carbon footprint in the upland rice cultivation.

The carbon stock change was measured using carbon stock in the secondary fallow forests. In the land preparation, it was found that carbon absorption was about $233.98 \mathrm{t} \mathrm{CO}_{2}$-eq/ha in the Lawa and $257.96 \mathrm{t} \mathrm{CO}_{2}$-eq/ha in the Karen. It was estimated that carbon sequestration in the aboveground biomass and the soils in the secondary fallow forests were $217.19 \mathrm{t} \mathrm{CO}_{2}$-eq/ha in the Lawa and $295.61 \mathrm{t} \mathrm{CO}_{2}$-eq/ha in the Karen. For the carbon footprint in the land preparation, it was found that the greenhouse gas absorption was $16.79 \mathrm{t} \mathrm{CO}_{2^{-}}$ eq/ha in Lawa plot while the greenhouse gas emission in the Karen was about $37.65 \mathrm{t} \mathrm{CO}_{2}$-eq/ha (Table 3). 
Table 3. Carbon stock and carbon emission in land use change ( $\left.\mathrm{CO}_{2} / \mathrm{ha}\right)$.

\begin{tabular}{|c|c|c|}
\hline Carbon content (t $\left.\mathrm{CO}_{2} \mathrm{eq} / \mathrm{ha}\right)$ & Lawa & Karen \\
\hline Stock in 6-years fallow forest & 217.19 & 295.61 \\
\hline Emission from land preparation process & -16.79 & 37.65 \\
\hline Emission from slashing & 22.56 & 57.84 \\
\hline $\begin{array}{l}\text { Emission from aboveground biomass } \\
\text { burning (non- } \mathrm{CO}_{2} \text { ) }\end{array}$ & 2.02 & 5.16 \\
\hline Soil carbon emission from burning & -41.37 & -25.35 \\
\hline Carbon stock change in land use change & 233.98 & 257.96 \\
\hline
\end{tabular}

The carbon footprint of the upland rice cultivation process was estimated from the material and chemical inputs (Table 4). Table 4 includes the input and output processes in the upland fields. It was found that the Lawa used organic fertilizer and insecticide in the cultivation process. The content of rice seeds, soil amendment, herbicide, nitrogen, fuel spray, and rice straw were significantly $(P<0.05)$ different when compared between the two groups. The upland rice seeds were from the previous season, which was $0.10 \mathrm{t} / \mathrm{ha}$ in the Lawa and $0.08 \mathrm{t} / \mathrm{ha}$ of Karen that could produce the upland rice yield of the Lawa and the Karen at 1.95 and $2.02 \mathrm{t} / \mathrm{ha}$, respectively. Costs of raw material inputs, causing GHG emission including chemical fertilizer, chemical application, organic fertilizer and soil amendment and gasoline of farm management, which used in the upland rice cultivation of the Karen and the Lawa were about 504 baht/rai and 676 baht/rai, respectively, at the 2015 constant price for the production. The carbon footprint of upland rice production per kilogram of the unmilled rice of the Lawa (about $0.37 \mathrm{t} \mathrm{CO}_{2}$-eq/ha or $0.19 \mathrm{~kg} \mathrm{CO}$-eq/kg unmilled rice) was slightly higher than the Karen $\left(0.26 \mathrm{t} \mathrm{CO}_{2}\right.$-eq/ha or $0.13 \mathrm{~kg} \mathrm{CO}$-eq/ $/ \mathrm{kg}$ unmilled rice) because the Lawa' farmers used more materials (such as organic fertilizer, soil conditioner and pesticide) for their cultivation while Karen farmers did not use these materials. The chemical fertilizer production was the main source of emission, contributing about $38-40 \%$ of the total, and the amount of $\mathrm{N}_{2} \mathrm{O}$ from chemical fertilizer was second, contributing 26-28\% of total GHGs (see details in Figure 3 and Figure 4). However, the carbon content in the upland rice production in the rotation shifting cultivation showed that carbon was absorbed in this system, which were $233.61 \mathrm{t} \mathrm{CO}_{2} /$ ha in the Lawa and $257.70 \mathrm{t} \mathrm{CO}_{2} /$ ha in the Karen (Figure $5)$. 
Table 4. Life cycle inventory of upland rice production (unit per hectare).

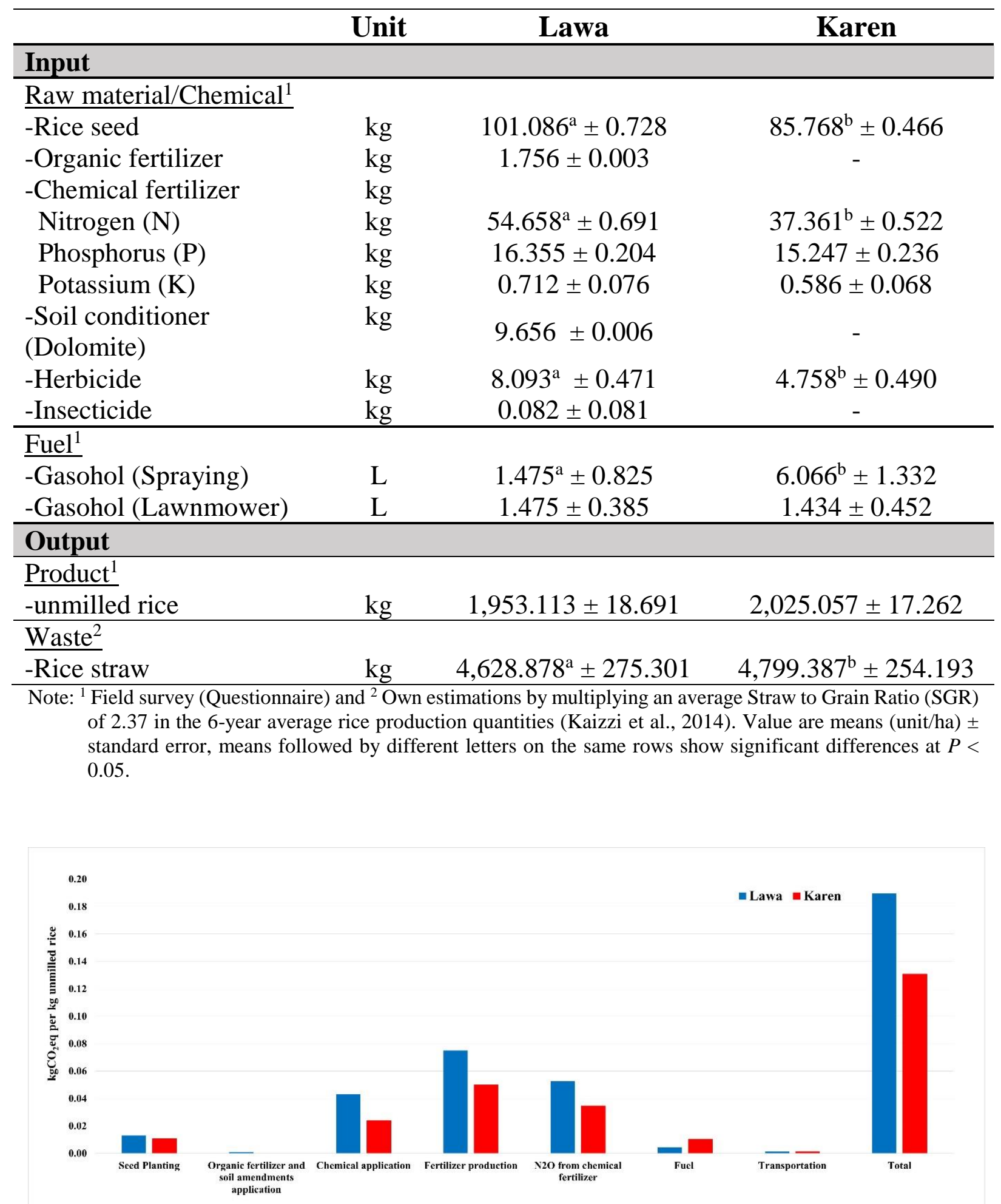

Figure 3. Carbon footprint of upland rice cultivation of the Lawa and Karen tribes $\left(\mathrm{kg} \mathrm{CO}{ }_{2}\right.$-eq/ $\mathrm{kg}$ unmilled rice). 
50

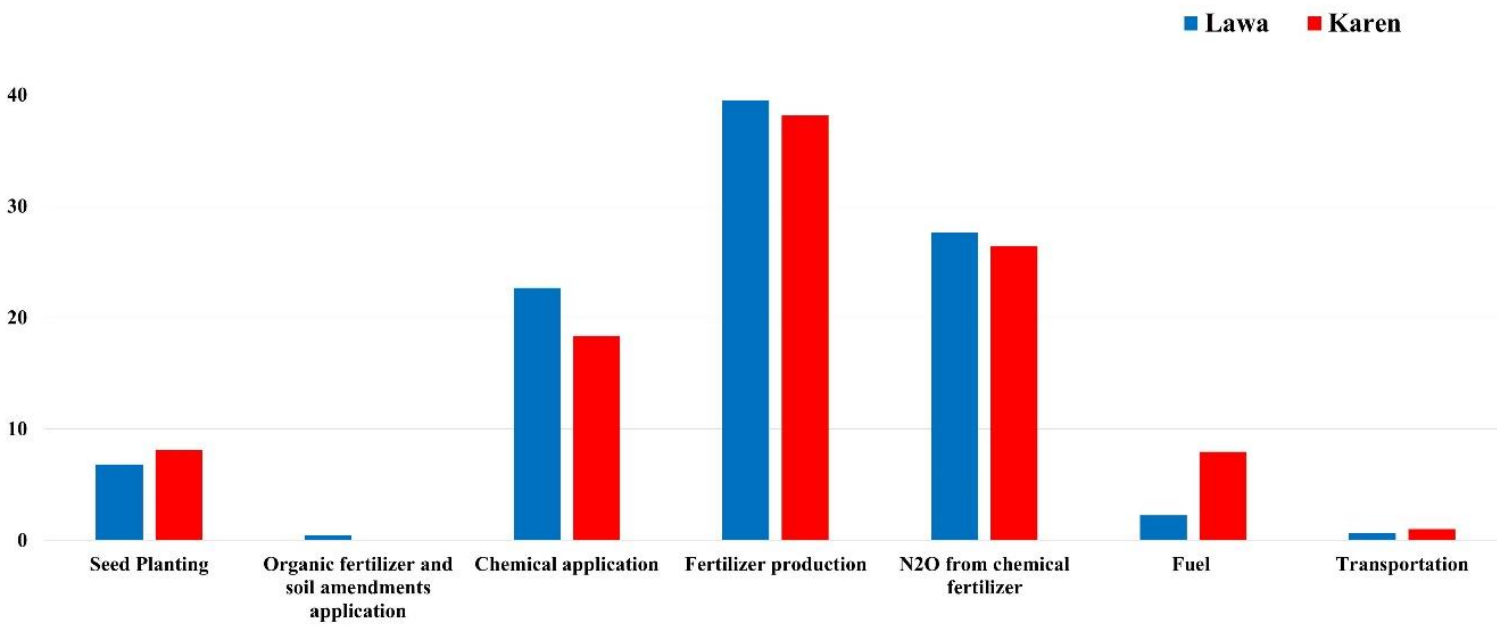

Figure 4. The proportion of carbon footprint in the upland rice cultivation process.

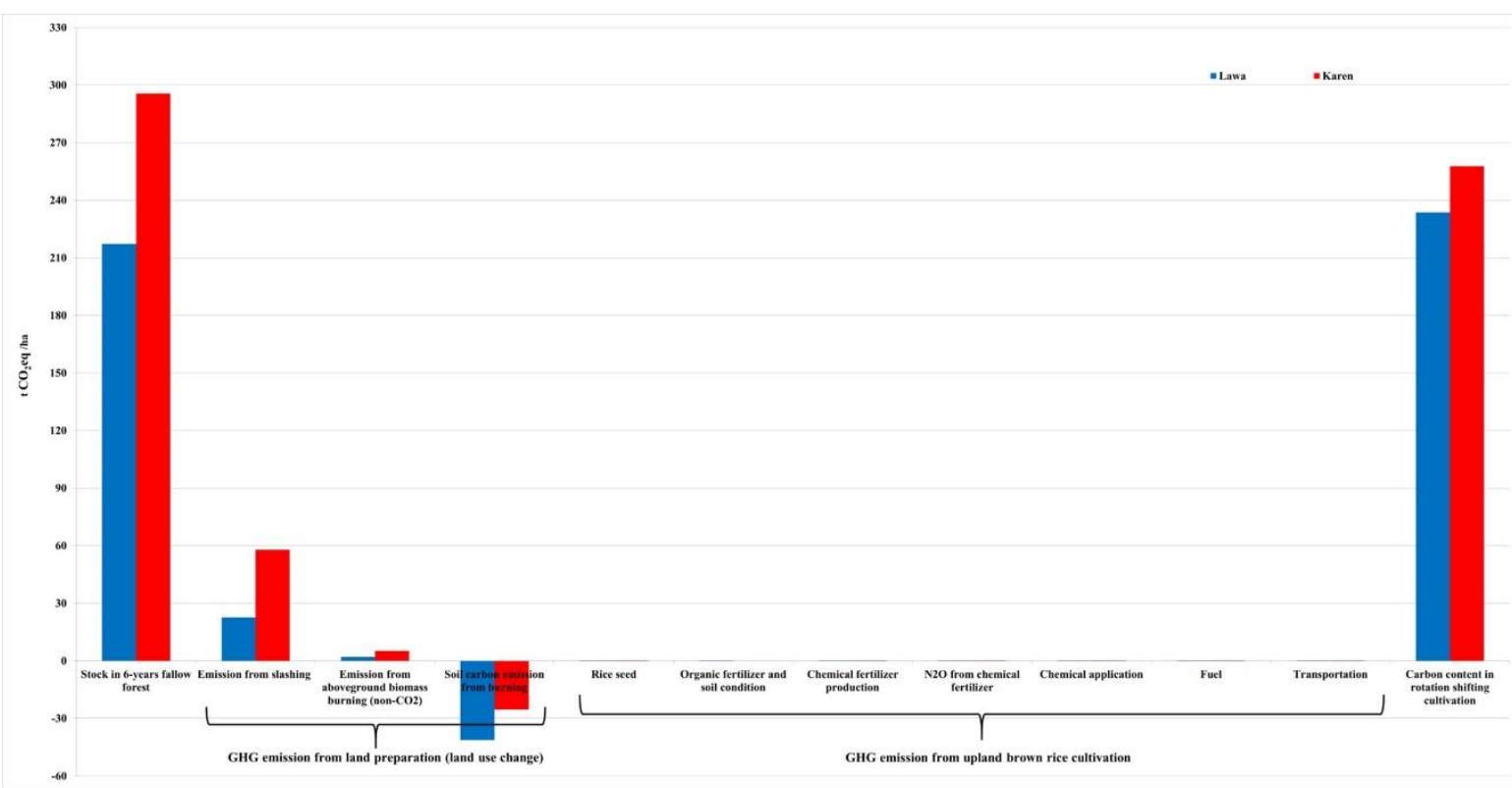

Figure 5. The carbon content in the upland rice production in the rotation shifting cultivation ( $\mathrm{t} \mathrm{CO}_{2}$-eq/ha).

\section{DISCUSSION}

In this study, greenhouse gas (GHG) emission of the upland rice production was emitted from the land preparation and the upland rice cultivation.

The land preparation is land-use change from secondary fallow forest to upland rice field including slashing and burning process. Most of GHGs emissions were from the aboveground residue burning and soils that released the 
non- $\mathrm{CO}_{2}$ gases $\left(\mathrm{CH}_{4}\right.$ and $\left.\mathrm{N}_{2} \mathrm{O}\right)$ into the atmosphere. IPCC (2006) assumed the $\mathrm{CO}_{2}$ emission of the biomass burning was zero because $\mathrm{CO}_{2}$ was captured through the photosynthesis process. The carbon absorption in the aboveground biomass and the $30-\mathrm{cm}$ soil depths were found in the two tribes after the burning process. Soil carbon was increased after burning process due to aboveground biomass, very fine root, and ashes from incomplete combustion (Zhao et al., 2012; Bodí et al., 2013; Nigh and Diemont, 2013).

In the cultivation process, the total rice yields depended on the field size, cultural practices, and field management (Hanafi et al., 2009). The upland rice yield is normally less than paddy rice yield because it is grown on stress conditions such as limited water, steep slope, low soil fertility, weeds, insects, diseases, low material input (chemical application) and agriculture machineries are not used for cultivation (Hanafi et al., 2009; Rautaray, 2011; Swamy and Kumar, 2012). Herbicide application rate in field depended on weed species, weed size, weed height, population thickness of weed in the fields and topography (Jamal, 2011). However, the life cycle GHG emission for the upland rice cultivation process seemed to be less than for other rice cultivation systems. Studies of paddy rice production showed that the carbon footprints of paddy rice were $1.90 \mathrm{~kg} \mathrm{CO}$-eq $/ \mathrm{kg}$ of rice (Farag et al., 2013), $4.87 \mathrm{~kg} \mathrm{CO}_{2}$-eq $/ \mathrm{kg}$ of rice in wet-season irrigation systems and $5.55 \mathrm{~kg} \mathrm{CO}$-eq $/ \mathrm{kg}$ of rice in dry-season irrigation systems (Perret et al., 2013), $1.39 \mathrm{~kg} \mathrm{CO}$-eq $/ \mathrm{kg}$ of rice (Brodt et al., 2014 ) and $1.52 \mathrm{~kg} \mathrm{CO}-\mathrm{eq} / \mathrm{kg}$ of rice for in-season and $1.27 \mathrm{~kg} \mathrm{CO}_{2}-\mathrm{eq} / \mathrm{kg}$ of rice for off-season rice ( $8^{\text {th }}$ Regional Office of Agricultural Economics, 2015), which are more than 10-fold those found in this study because the upland rice is nonflooded, so that it does not produce methane $\left(\mathrm{CH}_{4}\right)$. By comparison, Yodkhum et al. (2017) found that the GHG emissions of organic rice production were $0.58 \mathrm{~kg}$ $\mathrm{CO}_{2}$-eq/kg of paddy rice, which was lower than previous studies (Farag et al., 2013; Perret et al., 2013; Brodt et al., 2014; $8^{\text {th }}$ Regional Office of Agricultural Economics, 2015), while slightly higher than this study because the cultivation stage in their study did not input fertilizers and chemicals in the paddy rice fields. Farag et al. (2013) found the carbon emission from burning rice straw in paddy rice production was $0.68 \mathrm{~kg} \mathrm{CO}_{2}-\mathrm{eq} / \mathrm{kg}$ rice $(35.82 \%$ of the total), while upland rice straw was left in the field and not burnt after harvesting, so carbon dioxide was not emitted into the atmosphere from burning. Rossopa et al. (2012) studied the carbon footprint and mitigation emission in major rice production systems in Thailand. Retracing methane emission from rice fields showed that upland rice could absorb methane while the other kinds of rice fields, such as terrace rice, rainfed rice and irrigated rice, emitted methane into the atmosphere. In addition, Kägi et al. (2010) compared the LCA of rice products such as conventional, organic, and upland rice and found that upland rice has the lowest carbon footprint per kilogram of rice (about $1.60 \mathrm{~kg} \mathrm{CO}_{2}$-eq per $\mathrm{kg}$ of dry rice), lower than conventional and organic rice. However, upland rice fields can produce nitrous oxide $\left(\mathrm{NO}_{2}\right)$ from chemicals used in the fields while paddy rice (flooded rice) 
emits $\mathrm{CH}_{4}$ and $\mathrm{NO}_{2}$ which are more influential than carbon dioxide in driving climate change (Anand et al., 2005; IPCC, 2006).

The sustainability of the rotation shifting cultivation relies upon the inherited tradition knowledge and local wisdom of the Karen and the Lawa to restore and regenerate forests, soils, and land improvement, conservation of animal habitats and biodiversity, and sustainable use of natural resource because the carbon neutrality or carbon storage in secondary fallow forests (Fox et al., 2000; Bhagawati et al., 2015; Prakash et al., 2017). This tradition cultivation is for building up the harmonization of people in their community system to conservation and protection their inherited land for a sustainable way of food production in steep slope areas (ICIMOD, 2008). Costs of raw materials inputs in the upland rice cultivation, causing GHG emission, were lower than previous studies. For example, Junchoungchot (2014) found that the average cost of chemical and gasoline inputs of 818 baht/rai in scattering paddy rice cultivation in Samrongtarb District, Surin Province, and Department of Foreign Trade (2016) reported the average cost of rice cultivation in Ban Pahan District, Ayutthaya Province, was about 2,800 baht/rai. Furthermore, the upland rice yield of the two tribes was about 1,623-1,715 kg/household that is enough for livelihood consumption and rituals all year round because they did not purchase rice that was about 1,180 to 3,100 baht/100kg (Thai Rice Mills Association, 2015) in urban markets whose distances were about 67 to $76 \mathrm{~km}$ from their villages. This system is the longer traditional knowledge producing lower GHG emission and low price of upland rice cultivation, which is a low risk of human health and is environmental friendly in mountain areas (Ganpat and Isaac, 2015).

\section{CONCLUSION}

The carbon footprint of upland rice production in the rotation shifting cultivation in Northern Thailand through GHG emission was estimated through the life cycle of the product using an environmental impact assessment. This research found that the carbon balance in the land preparation to upland rice cultivation was absorption in the Lawa, about $16.42 \mathrm{t} \mathrm{CO}_{2}-\mathrm{eq} / \mathrm{ha}$ in the Lawa, while the carbon emission in the Karen was about $37.91 \mathrm{t} \mathrm{CO}_{2}$-eq/ha. Moreover, upland rice cultivation is not a flooded system and the rice straw is not burnt after harvesting, resulting in a low carbon footprint, however, the reduction of impacts should be concentrated upon improvement and management of residues in slashand-burn process and chemicals in cultivation stage of the life cycle of upland rice production. This study demonstrated that the carbon footprint of the upland rice production of the Lawa tribe was higher than the Karen tribe because of chemicals the Lawa used for cultivation. However, the overall carbon in this system was absorption, about $233.61 \mathrm{t} \mathrm{CO}_{2}$-eq/ha in the Lawa and $257.70 \mathrm{t} \mathrm{CO}_{2}$ eq/ha in the Karen. The rotation shifting cultivation represents carbon absorption more than carbon emission. This sysem is tradition knowledge used for 
sustainable agriculture management on steep slopes in mountain areas. However, in the present, the population growth and the governmental pressure to reduce rotation shifting cultivation and forestland allocation causes the shortening of fallow periods that can lead to reduction in the sustainability of the rotation shifting cultivation.

\section{ACKNOWLEDGEMENTS}

This study was supported by grants funded by the National Research Council of Thailand (NRCT) and the Graduate School of Chiang Mai University. The authors wish to thank the Environmental Science program and the Department of Biology, Faculty of Science, Chiang Mai University and the World Agroforestry Centre (ICRAF) of Thailand. This research was partially funded by Chiang Mai University.

\section{REFERENCES}

$8^{\text {th }}$ Regional Office of Agricultural Economics. 2015. The assessment of greenhouse gas emission of rice cultivation in Pak Pa-Nung River basin in Nakornsrithammarat, Thailand

Anand, S., Dahiya, R.P., Talyan, V., and Vrat, P. 2005. Investigations of methane emissions from rice cultivation in Indian context. Environment International. 31: 469 - 482. https://doi.org/10.1016/j.envint.2004.10.016 AquAeTer. 2016. What is Life Cycle Assessment? What are the Elements Needed for a Life Cycle Assessment? [online] Available: http:// woodpoles.org/

Arunrat, N., and Pumijumnong, N. 2017. Practices for reducing greenhouse gas emissions from rice production in northern Thailand. Agriculture Journals. 7(4): 1-20. https://doi.org/10.3390/agriculture7010004

Asia Indigenous Peoples' Pact (AIPP) and the International Work Group for Indigenous Affairs (IWGIA), Chiang Mai. 2014. Shifting Cultivation, Livelihood and Food Security: New and Old Challenges for Indigenous Peoples in Asia. The full research reports by AIPP and IWGIA in 2014.

Aweto, A.O. 2013. Shifting cultivation and secondary succession in the tropics. Boston, MA: CABI. p. 216.

Bhagawati, K., Bhagawati, G., Das, R., Bhagawati, R., Ngachan, S.V. 2015. The structure of Jhum (traditional shifting cultivation system): prospect or threat to climate. International Letters of Natural Sciences. 46: 16-30.

Blake, G.R., and Hartge, K.H. 1986. Bulk density. In: Klute, A., editor. Methods of soil analysis. Part I. Physical and mineralogical methods. Soil science society of America, Inc., Madison, WI. 363-376. 
Boateng, K.K., Obeng, G.Y., and Mensah, E. 2017. Rice cultivation and greenhouse gas emissions: a review and conceptual framework with reference to Ghana. Agricultural Journals. 7(1): 1-14.

Bodí, M.B., Martin, D.A., Balfour, V.N., Santín, C., Doerr, S.H., Pereira, P., Cerdà, A., and Mataix-Solera, J. 2013. Wildland fire ash: production, composition and eco-hydro-geomorphic effects. Earth-Science Reviews. 130: 103-127. https://doi.org/10.1016/j.earsciev.2013.12.007

Brodt, S., Alissa, K., Yaser, M., Aslihan, A., Juhing, Y., In-Sung, L., and Bruce, L. 2014. Life cycle greenhouse gas emissions in California rice production. Field Crops Research. 169: 89-98.https://doi.org/10.1016/jfcr. 2014.09.007

Cairns, M. 2007. Voices from the forest. Integrating indigenous knowledge into sustainable upland farming. Resource for the Future Washington D.C., USA.

Cairns, M. 2015. Shifting cultivation and environmental change: indigenous people, agriculture and forest conservation.

Carbon Trust. 2007. Carbon Footprint Methodology. Carbon Trust, UK. [online] Available: www.carbontrust.co.uk/

Curran, M.A. 2006. Life cycle assessment: principles and practice. Science inventory. Environmental Protection Agency (EPA), Washington, DC. 68C02-067 (3-15): 1-80.

Department of Foreign Trade. 2016. Data of rice production of farmer on 21 January 2016 from Thailand Development Research Institute. Data of rice production and rice trading.

Dixon, R.K., Brown S, Solomon R.A., Trexler M.C., and Wisniewski J. 1994. Carbon pools and flux of global forest ecosystem. Science. 263:185-190. https://doi.org/10.1126/science.263.5144.185

Farag, A.A., Radwan, H.A., Abdrabbo, A.A., Hehhi, M.A.M., and McCarl, B.A. 2013. Carbon footprint for paddy rice production in Egypt. Nature and Science. 11(12): 36-45.

Fox, J., Truong, D.M., Rambo, A.T., Tuyen, N.P., Cuc, L.T., and Leisz, S. 2000. Shifting cultivation: a new old paradigm for managing tropical forests. Bioscience Journal. 50: 521-528. https://doi.org/10.1641/00063568(2000)050[0521:SCANOP]2.0.CO;2

Ganpat, W.G., and Isaac, W.A.P. 2015. Farming adaptations to the impacts of climate change and extreme events. Impacts of climate change on food security in small island developing states. 185-186.

Hanafi, M.M., Hartinie, A. Shukor, J., and Mahmud, T.M.M. 2009. Upland rice varieties in Malaysia: Agronomic and soil physico-chemical characteristics. Pertanika Journal of Tropical Agriculture. 32(2): 225-246.

Higashi, S. 2014. Shifting cultivation and upland life in Northern Laos. Nature and Our Future: The Mekong Basin and Japan. p. 1-5. 
Holden, S.T. 1993. Peasant household modelling: farming systems evolution and sustainability in northern Zambia, Agricultural Economics. 9: 241-267. https://doi.org/10.1016/0169-5150(93)90050-M

International Center for Integrated Mountain Development (ICIMOD). 2008. The Right to Practise Shifting Cultivation in Nepal: Lessons from ILO Conventions Nos. 111 and 169.

Intergovernmental Panel on Climate Change (IPCC). 2006. Agriculture; methane emissions from rice cultivation: Flooded rice fields. Guidelines for National Greenhouse Gas Inventories: Reference Manual [online] Available: http://www.ipcc-nggip.iges.or.jp/

Intergovernmental Panel on Climate Change (IPCC). 2007. Climate change 2007: Synthesis Report. Contribution of Working Groups I, II and III to the Fourth Assessment Report of the Intergovernmental Panel on Climate Change [Core Writing Team, Pachauri, R.K and Reisinger, A., editor.]. IPCC, Geneva, Switzerland. p. 104.

The International Organization for Standardization (ISO) 14001. 2004. Environmental management systems - requirements with guidance for use. The International Organization for Standardization. p. 35.

International Organisation for Standardisation (ISO) 14040. 2006. Environmental management - Life cycle assessment - Principles and framework, Geneve. p. 20.

Jain, N., Pathak, H., Mitra, S., and Bhatia, A. 2004. Emission of methane from rice fields-A review. Journal of Scientific and Industrial Research. 63: 101115.

Jamal, R.Q. 2011. Herbicides applications: problems and considerations, herbicides and environment, Dr. Andreas Kortekamp, editor. ISBN: 978953-307-476-4, InTech.

Janchoungchot, W. 2014. Comparison of cost and return on Hom Mali 105 rice cultivation between scattering and scattering with transplanting methods of farmers in samrongtarb district, Surin province. [thesis]. [Bangkok]: Rajamangala University of Technology Thanyaburi.

Jeeva, S.R.D.N., Laloo, R.C., and Mishra, B.P. 2006. Traditional agricultural practices in Meghalaya, North East India. Indian Journal of Traditional Knowledge. 5(1): 7-18.

Kägi, T., Wettstein, D., and Dinkel, F. 2010. LCA of rice: confidence intervals for avoiding wrong conclusions. LCA Food 2010, VII international conference on LCA in the agri-food sector. Bari, Italia, September 22-24, 2010.

Kaizzi, K.C., Byalebeka, J., Semalulu, O., Alou, I., Zimwanguyizza, W., Nansamba, A., Odama, E., and Wortmann, C.S. 2014. Upland rice response to nutrient application in Uganda. African Journal of Plant Science. 8(9): 416-425. https://doi.org/10.5897/AJPS2014.1175 
Khalil, M.A.K., Shearer, M.J., Butenhoff, C.L., Xiong, Z.Q., Rasmussen, R.A., $\mathrm{Xu}, \mathrm{L}$. , and Xing, G. 2011. Emissions of Greenhouse Gases from Rice Agriculture. p. 22.

Kreuz, A., and Schäfer, E. 2011. Weed finds as indicators for the cultivation regime of the early Neolithic Bandkeramik culture? Vegetation history and Archaeobotany. The Journal of Quaternary Plant Ecology, Palaeoclimate and Ancient Agriculture. 20(5): 333-348.

Li, C.S., Frolking, S., Xiao, X.M., Moore, B. III, Boles, S., Qiu, J., Huang, Y., Salas, W., and Sass, R. 2005. Modeling impact of farming management alternatives on $\mathrm{CO}_{2}, \mathrm{CH}_{4}$, and $\mathrm{N}_{2} \mathrm{O}$ emissions: a case study for water management of rice agriculture of China. Global Biogeochemical Cycles. 19(3): 1-10. https://doi.org/10.1029/2004GB002341

Mae Cheam Watershed Research Station. 2015. Mae Cheam District, Chiang Mai: average annual weather in 2015. Retrieved from:http://www.dnp. go.th/watershed/research

Manitoba Eco-Network. 2016. $\mathrm{CO}_{2}$ equivalents. Emissions [online] Available: http://climatechangeconnection.org/emissions/co2-equivalents/

Mukul, S.A., Herbohn, J., and Firn, J. 2016. Tropical secondary forests regenerating after shifting cultivation in the Philippines uplands are important carbon sinks. Scientific Reports. 6(22483): 1-12. https://doi.org/10.1038/srep22483

Nemecek, T., Dubois, D., Huguenin-Elie, O., and Gaillard. 2011. Life cycle assessment of Swiss farming systems: I. Integrated and organic farming. Agricultural Systems. 104(3): 217-232. https://doi.org/10.1016/j.agsy. 2010.10.002

Nigh, R. and Diemont, A.W. 2013. The Maya milpa: fire and the legacy of living soil. Frontiers in Ecology and the Environment (11) (Online Issue 1): 4554. https://doi.org/10.1890/120344

Oikeh, S.O., Nwilene, F.E., Agunbiade, T.A., Oladimeji, O., Ajayi, O., Mande, S., Tsunematsu, H., and Samejima, H. 2008. Growing upland rice: a production handbook. Africa Rice Center, Benin. p. 40

Perret, S-R., Thanawibg, K., Basset-Mens, C., and Mungkung, R. 2013. The environmental impacts of lowland paddy rice: a case study comparison between rainfed and irrigated rice in Thailand. Cahiers Agricultures. 22(5): 1-9. https://doi.org/10.1684/agr.2013.0663

Prakash, N., Roy, S.S., Ansari, M.A., Sharma, S.K., Punitha, P., Sailo, B., and Singh, I.M. 2017. Jhum improvement for sustaining farm livelihood and natural resource conservation in North Eastern Hill Region: vistas and frontiers. Indian Council of Agricultural Research. ICAR Research Complex for Neh Region, Meghalaya. 
Rossopa, B., Budhaboon, C., Kunket, K., Wongboon, W., Hantanapong, A., Inthaleang, S, and Prayoonsuk, N. 2012. Carbon footprint and mitigation emission in major rice production system in Thailand: retrace methane emission from rice field. Proceeding of rice research conference 2012: Rice research center groups in central, eastern and western region.

Rautaray, S.K. 2011. Upland rice (Ahu) in Assam. Upland rice in India. Scientific Publishers. 32-58.

Rozendaal, D.M.A., and Chazdon, R.L. 2015. Demographic drivers of tree biomass change during secondary succession in northeastern Costa Rica. Ecological Applications. 25: 506-516. https://doi.org/10.1890/14-0054.1

Sachakamol, P. 2016. Life Cycle Assessment (LCA) [online] Available: http://fic.nfi.or.th/waterfootprint/images/pdf/1seminar2_assetment4.pdf .

Scheidel, A. 2016. Carbon accounts of shifting cultivation: reductionist practices, contentious politics. International Institute of Social Studies (ISS), The Hague, Erasmus University Rotterdam, Netherlands.

Schmidt-Vogt, D. 1999. Swidden farming and fallow vegetation in northern Thailand. Geoecological Research, Vol.8. Stuttgart: Franz Steiner Verlag, Germany. p. 373.

Swamy, B.P.M., and Kumar, A. 2012. Sustainable rice yield in water-short drought-prone environments: conventional and molecular approaches. In: Irrigation Systems and Practices in Challenging Environments by Teang Shui Lee [Ed]. InTech (Shang-hai). 149-168.

Thai National LCI Database/MTEC. 2015. Emission Factor (Update June 2016). Thai Rice Mills Association. 2015. The white rice prices in November and December 2015. Retrieved from:http://www.thairicemillers.org/

Thailand Greenhouse Gas Management Organization, TGO (Public Organization). 2012. Greenhouse gases - Carbon footprint of products Requirements and guideline for quantification and communication.

Thailand Greenhouse Gas Management Organization (Public Organization) (TGO). 2015. Emission Factor CFP (ver. Update September 2015) [online] Available: http://thaicarbonlabel.tgo.or.th/

Thailand Greenhouse Gas Management Organization, TGO (Public Organization) (TGO). 2016. Carbon emission calculation [online] Available: http://tver.tgo.or.th/

Tinker, P.B., Ingram, J., and Struwe, S. 1996. Effects of slash-and-burn agriculture and deforestation on climate change. Agriculture, Ecosystems and Environment. 58: 13-22. https://doi.org/10.1016/0167-8809(95)006 $51-6$

Tsutsumi, T., Yoda, K., Sahunalu, P., Dhanmanonda, P., and Prachaiyo, B. 1983. Forest: felling, burning and regeneration. In Kyuma, K., and Pairintra, C., editors. Shifting cultivation, Tokyo. 13-62. 
Walkley, A., and Black, I.A. 1934. An examination of the Degtjareff method for determining soil organic matter, and a proposed modification of the chromic acid titration method. Soil Science. 37: 29-38.

Watthanasuksakun, S., Phonleeseansuwan, A., Chattaecha, P., and Nongnuang, S. 2013. Soil properties, soil carbon and nutrient accumulations in 18 yearold Pinus caribaea Morelet Plantation. Academic Conference on Thai Forest Ecological Research Network: Ecological knowledge for restoration; Chiang Mai: Maejo University. P.227-235.

Weller, S., Kraus, D., Ayag, K.R.P., Wassmann, R., Alberto, C.R., Butterbach-Bahl, K., Kiese, R. 2014. Methane and nitrous oxide emissions from rice and maize production in diversified rice cropping systems. Nutrient Cycling in Agroecosystems. 101: 37-53. https://doi. org/10.1007/s10705-014-9658-1

Wenzlau, S. 2019. UN says sustainable farming can help close global emissions gap. Vision for a Sustainable Word. Worldwatch Institute [online] Available: http://www.worldwatch.org/

Yamane, T. 1967. Statistics, an introductory analysis, $2^{\text {nd }}$ ed., New York: Harper and Row. p. 919.

Yodkhum, S., Gheewala, S.H., and Sampattagul, S. 2017. Life cycle GHG evaluation of organic rice production in northern Thailand. Journal of Environmental Management. 196: 217-223. https://doi.org/10.1016/j. jenvman.2017.03.004

Yuttitham, M. 2019. Comparison of carbon footprint of organic and conventional farming of Chinese Kale. Environment and Natural Resources Journal. 17(1): 78-92. https://doi.org/10.32526/ennrj.17.1.2019.08

Zhao, H., Tong, D. Q., Lin, Q., Lu, X., and Wang, G. 2012. Effect of fires on soil organic carbon pool and mineralization in a northeastern China wetland. Geoderma. 189-190: 532-539. https://doi.org/10.1016/j.geoderma.2012. 05.013

Zheng, X., Han, S. Huang, Y., and Wang, M. 2004. Re-quantifying the emission factors based on field measurement and estimating the direct $\mathrm{N}_{2} \mathrm{O}$ emission from Chinese croplands. Global Biogeochemical Cycles. 18: GB2018. 